\title{
Dietmar Straile \\ Meteorological forcing of plankton dynamics in a large and deep continental European lake
}

Received: 15 February 1999 / Accepted: 23 August 1999

\begin{abstract}
The timing of various plankton successional events in Lake Constance was tightly coupled to a largescale meteorological phenomenon, the North Atlantic Oscillation (NAO). A causal chain of meteorological, hydrological, and ecological processes connected the NAO as well as winter and early spring meteorological conditions to planktonic events in summer leading to a remarkable memory of climatic effects lasting over almost half a year. The response of Daphnia to meteorological forcing was most probably a direct effect of altered water temperatures on daphnid growth and was not mediated by changes in phytoplankton concentrations. High spring water temperatures during "high-NAO years" enabled high population growth rates, resulting in a high daphnid biomass as early as May. Hence, a critical Daphnia biomass to suppress phytoplankton was reached earlier in high-NAO years yielding an early and longerlasting clear-water phase. Finally, an earlier summer decline of Daphnia produced in a negative relationship between Daphnia biomass in July and the NAO. Meteorological forcing of the seasonal plankton dynamics in Lake Constance included simple temporal shifts of processes and successional events, but also complex changes in the relative importance of different mechanisms. Since Daphnia plays an important role in plankton succession, a thorough understanding of the regulation of its population dynamics provides the key for predictions of the response of freshwater planktonic food webs to global climate change.
\end{abstract}

Key words NAO - Daphnia Populations dynamics . Seasonal succession $\cdot$ Ecological memory

\footnotetext{
D. Straile (区)

Limnologisches Institut, Universität Konstanz,

D-78457 Konstanz, Germany

e-mail: dietmar.straile@uni-konstanz.de

Fax: +49-7531-883533
}

\section{Introduction}

Climatic forcing is increasingly recognized as an important factor causing interannual variability in organism abundances in both aquatic and terrestrial ecosystems (George and Harris 1985; Aebischer et al. 1990; Roemmich and McGowan 1995; Adrian et al. 1995; George and Taylor 1995; Adrian and Deneke 1996; Fromentin and Planque 1996). Many long-term time series show a close coupling between large-scale meteorological phenomena and changes in population densities. For example, effects of the El Niño Southern Oscillation (ENSO) are apparent in oceanic and limnetic time series from Lake Tahoe (USA) to Tasmania (Barber and Chavez 1983; Strub et al. 1985; Harris et al. 1988; Karl et al. 1995; Anderson et al. 1996). Although there may be some linkages between the ENSO and weather patterns in Europe (Fraedrich and Müller 1992), it has become increasingly clear during recent years that the North Atlantic Oscillation (NAO) drives the weather patterns in the region of the northern hemisphere north of $20^{\circ} \mathrm{N}$ (Lamb and Peppler 1987; Hurrell 1995; Davies et al. 1998).

The NAO is a large-scale oscillation of atmospheric mass between the North Atlantic regions of subtropical high surface pressures, the Azores High, and subpolar low surface pressures, the Iceland Low (Lamb and Peppler 1987). The occurrence of warm winters over much of Europe during the late 1980s and early 1990s was associated with anomalously low pressures in the region of the Icelandic Low and with pressures higher than normal at lower latitudes, corresponding to a high positive NAO index (Hurrell 1995). There is growing evidence that the abundances of aquatic and terrestrial species were influenced by the NAO (Fromentin and Planque 1996; Fromentin et al. 1998; Kröncke et al. 1998; Post and Stenseth 1998).

Despite convincing evidence for climatic forcing on planktonic ecosystems, the mechanisms behind climatic impacts are often only poorly understood (Aebischer et al. 1990). These shortcomings in our understanding of 
meteorological forcing in planktonic food webs are due in part to a rather low temporal resolution of long-term data series, with sampling intervals exceeding the generation times of many of the organisms involved. A strong correlation was recently established between the NAO and daphnid biomass in Lake Constance, a large continental lake approximately $1000 \mathrm{~km}$ from the Atlantic Ocean (Straile and Geller 1998a). The plankton time series available for Lake Constance spans 15 years of observations with a high temporal resolution, i.e., weekly sampling intervals during the growing season, therefore enabling a detailed causal analysis of the meteorological forcing of plankton succession. The purpose of this study was (a) to evaluate the mechanisms by which the NAO affects daphnid biomass in Lake Constance, and (b) to analyze the indirect effects of climate forcing which arise from alternations in daphnid biomass during different parts of the season.

\section{Materials and methods}

Lake Constance is a large $\left(472 \mathrm{~km}^{2}\right)$ and deep $\left(z_{\max }=254 \mathrm{~m}\right)$, temperate $\left(47^{\circ} 39^{\prime} \mathrm{N}\right)$ lake on the northern fringe of the Alps. The seasonal dynamics of phytoplankton, zooplankton, and microbial populations have been studied in great detail (Simon and Tilzer 1987; Tilzer and Beese 1988; Geller 1989; Müller et al. 1991; Gaedke 1993; Straile 1998; Straile and Geller 1998b). Samples for the present study were taken weekly during the growing season and approximately fortnightly during winter in the central part of the fjord-like northwestern part of the lake (Überlinger See) from 1979 to 1994 . No zooplankton samples were taken during 1983 and no phytoplankton samples were taken from July to December 1983. Zooplankton were collected with a Clarke-Bumpus sampler (mesh size $140 \mu \mathrm{m})$ by vertical hauls from $140 \mathrm{~m}$ depth. The zooplankton community consists of two Daphnia species, D. hyalina and D. galeata, Bosmina sp., Leptodora kindti, Bythotrephes longimanus, Eudiaptomus gracilis, and three cyclopoid copepod species (Straile and Geller 1998b). Daphnid biomass was calculated from length-dry weight relationships established for Lake Constance (Geller and Müller 1985). Phytoplankton biovolume was obtained by counting the abundance of individual species and morphotypes with the Utermöhl technique and allocating fixed cell volumes to each species (Gaedke and Schweizer 1993). Average increase rates of phytoplankton biovolume during May were calculated based on data smoothed with a three-point movingaverage filter and assuming exponential increase, i.e., $r=\left[\ln \left(\mathrm{BV}_{\mathrm{LM}}\right)-\ln \left(\mathrm{BV}_{\mathrm{FM}}\right)\right] / T$, where $\mathrm{BV}_{\mathrm{FM}}$ and $\mathrm{BV}_{\mathrm{LM}}$ are the phytoplankton biovolumes on the first and last sampling days in May in the respective years and $T$ is the time span between these two sampling dates. Data on underyearling year-class strength of whitefish (Coregonus lavaretus), which is the dominant planktivore in the lake were taken from Eckmann et al. (1988) and Eckmann and Rösch (1998). Water transparency was recorded with a Secchi disk of $30 \mathrm{~cm}$ diameter. The start of the clear-water phase was defined as the first sampling date after the algal spring bloom with Secchi depth exceeding $7 \mathrm{~m}$. Air temperatures were measured at the nearby meteorological station at Constance and provided by the German Weather Service. Water temperature for various depths was recorded at the respective sampling dates in the years 1979, 1980, 1981, and 1986 and continuously (every $20 \mathrm{~min}$ ) during the other years. For the present study, water temperatures at $8 \mathrm{~m}$ depth were used, which is approximately the residence depth of daphnids during spring (Geller 1986). The NAO index was taken from Hurrell (1995) and calculated as the difference between the normalized sea level pressure (SLP) anomalies during winter (December-March) at Lisbon, Portugal, and Stykkisholmur, Iceland. The SLP anomalies at each station were normalized by dividing each seasonal pressure by the long-term standard deviation (Hurrell 1995). Data analysis was performed using SAS (SAS 1988).

\section{Results}

Average air temperatures in Constance varied from -1 to $4^{\circ} \mathrm{C}$ during winter (December-March) and warm average air winter temperatures were associated with high-NAO years $(r=0.62, P<0.05$; Table 1$)$. Lake Constance was not covered by ice during the study period, an event which has occurred only once during the 20th century. Not surprisingly, epilimnetic water temperatures were positively related to air temperatures and, hence, to the NAO. Significant positive correlations between the NAO and water temperatures with coefficients of determination exceeding 0.3 were found until May (Fig. 1). From June onwards, variability in water temperatures was no longer related to the variability in the NAO in winter.

In contrast to spring water temperature, phytoplankton biomass was only weakly related to the NAO in March ( $r=0.4, P<0.12$; Fig. 2a), but not during April and May ( $r=0.09$, n.s. and $\mathrm{r}=-0.12$, n.s., respectively; Fig. $2 b, c)$. Daphnia biomass was low during the beginning of the year, increased on average by three orders of magnitude during a period of exponential growth in April and

Table 1 Pearson correlation coefficients of meteorological and successional parameters at Lake Constance. Correlations were significant at ${ }^{\circ} P<0.1, \quad * P<0.05, \quad * * P<0.01, \quad * * * P<0.005$,

$* * * * P<0.001$ or not significant (n.s.). Daphnia biomass was logtransformed prior to analysis

\begin{tabular}{|c|c|c|c|c|c|c|c|}
\hline & $\begin{array}{l}\text { Winter air } \\
\text { temperature } \\
\left({ }^{\circ} \mathrm{C}\right)\end{array}$ & $\begin{array}{l}\text { Water } \\
\text { temperature } \\
\text { (April/May) } \\
\left({ }^{\circ} \mathrm{C}\right)\end{array}$ & $\begin{array}{l}\text { Daphnia } \\
\text { growth rate } \\
\text { (April/May) } \\
\left(\text { day }^{-1}\right)\end{array}$ & $\begin{array}{l}\text { Daphnia } \\
\text { biomass } \\
\text { (May) } \\
\left(\mathrm{mg} \mathrm{C} / \mathrm{m}^{-2}\right)\end{array}$ & $\begin{array}{l}\text { Start of } \\
\text { clear-water } \\
\text { phase } \\
\text { (julian day) }\end{array}$ & $\begin{array}{l}\text { Daphnia } \\
\text { biomass } \\
\text { (July) } \\
\left(\mathrm{mg} \mathrm{C} / \mathrm{m}^{-2}\right)\end{array}$ & $\begin{array}{l}\text { Duration of } \\
\text { clear-water } \\
\text { phase } \\
\text { (days) }\end{array}$ \\
\hline NAO index & $0.63 *$ & $0.78 * * * *$ & $0.53 *$ & $0.64 *$ & $-0.55 *$ & $-0.58 *$ & $0.46^{\circ}$ \\
\hline Air temperature & & $0.61 *$ & $0.74 * * *$ & $0.81 * * * *$ & $-0.58 *$ & $-0.45^{\circ}$ & 0.23 n.s. \\
\hline $\begin{array}{l}\text { Water temperature } \\
\text { (April/May) }\end{array}$ & & & $0.64 *$ & $0.63 *$ & $-0.54 *$ & $-0.59 *$ & $0.52 *$ \\
\hline Daphnia growth rate & & & & $0.82 * * * *$ & $-0.66 * *$ & $-0.54 *$ & 0.3 n.s. \\
\hline Daphnia biomass (May) & & & & & $-0.84 * * * *$ & $-0.69 * * *$ & 0.4 n.s. \\
\hline Start clear-water phase & & & & & & $0.63^{*}$ & $-0.58 *$ \\
\hline Daphnia biomass (July) & & & & & & & -0.09 n.s. \\
\hline
\end{tabular}




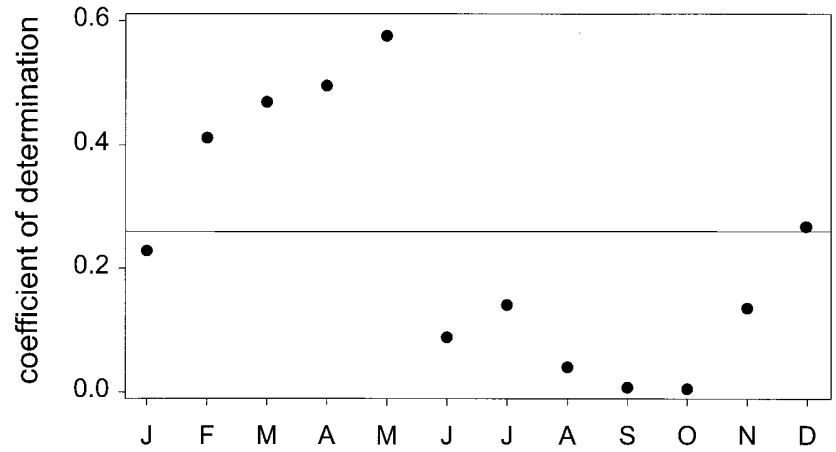

Fig. 1 Coefficient of determination $\left(r^{2}\right)$ of the relationship between the North Atlantic Oscillation (NAO) index and the average water temperature at $8 \mathrm{~m}$ depth during individual months from 1979 to 1994 . The horizontal line indicates a significance level of 95\%. The NAO index for December to March has a predictive power for the water temperatures at $8 \mathrm{~m}$ depth up to May but not later in the year

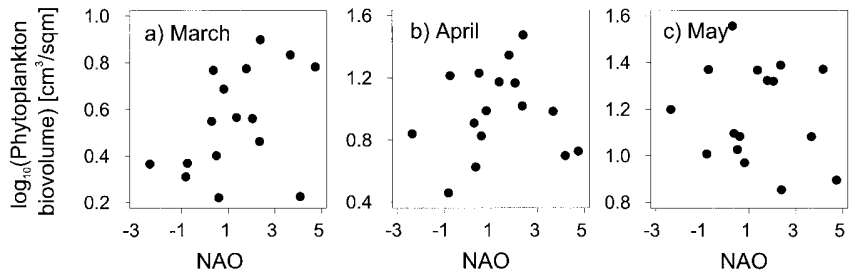

Fig. 2 Relationship between the NAO index and monthly averages of phytoplankton biomass in March $(r=0.4, P<0.12)$ (a), April $(r=0.09$, n.s. $)(\mathbf{b})$, and May $(r=-0.12$, n.s. $)(\mathbf{c})$

May, and remained at a rather high level compared to winter biomasses until the end of the year (Fig. 3). As average net population growth rates during April and May in most years could be adequately described by an exponential model, they were estimated from the slope of a linear regression line fitted to the relationship between the logarithm of Daphnia biomass and the day of the year. Combining data from all study years, daphnid biomass increased by 0.043 per day $\left(r^{2}=0.49, P<0.0001\right)$ during April and May. I tested for significant differences in population growth rates between years using an ANCOVA approach with $\log _{10}$ (biomass) as the dependent variable and day of the year, year, and their interaction as independent variables (Table 2). Significant differences in population growth rates between years were suggested by a significant interaction term. Daphnid growth rates during April/May of individual years ranged between 0.02 day $^{-1}$ in 1987 and 0.09 day $^{-1}$ in 1990 and differences were related to the variability in average April/May water temperatures $(r=0.64, P<0.05)$ and consequently indirectly to the NAO $(r=0.53$, $P<0.05)$. There was neither a significant relationship between Daphnia growth rates and algal biovolumes during April ( $r=-0.07$, n.s.) nor during ( $r=-0.3$, n.s.). In addition, a multiple regression model which included algal biovolumes and May water temperature did not explain more variability in Daphnia growth rates than water tem-

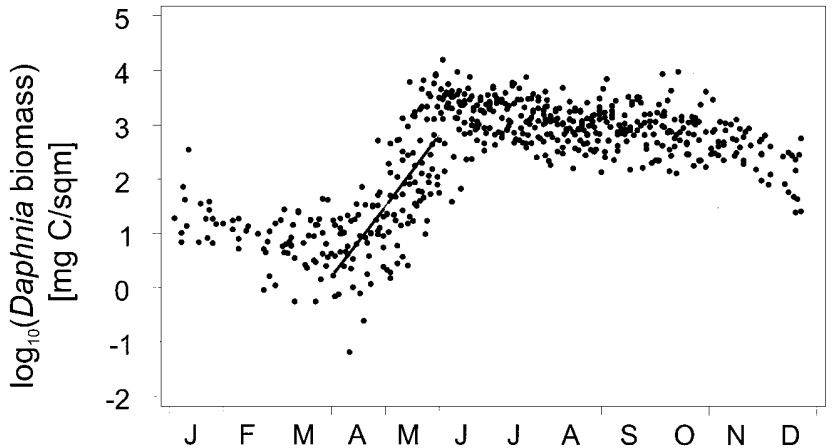

Fig. 3 Individual observations of daphnid biomass throughout 1979-1994. The line indicates the mean net population increase during April and May when considering all study years

Table 2 ANCOVA with Daphnia biomass on individual sampling dates in April and May (dependent variable) and julian day, year, and their interaction as independent variables

\begin{tabular}{lcrrl}
\hline Source & $d f$ & Type III SS & $F$-value & $\operatorname{Pr}<F$ \\
\hline Julian day & 1 & 62.9 & 179.53 & 0.0001 \\
Year & 14 & 8.3 & 1.70 & 0.0681 \\
Julian day $\times$ year & 14 & 10.3 & 2.09 & 0.0185 \\
Error $d f$ & 97 & & & \\
Error SS & 34 & & & \\
$R^{2}$ & 0.77 & & & \\
\hline
\end{tabular}

perature alone, i.e., algal biovolumes did not contribute significantly to the model.

High daphnid growth rates correlated with high daphnid biomass during May, which linked daphnid biomass in May to water temperatures during April/May $(r=0.63, P<0.05)$ and the NAO (Straile and Geller 1998a). Daphnia biomass in May did not depend on the size of the overwintering Daphnia population as there were no significant correlations between Daphnia biomasses in May and March ( $r=-0.08$, n.s.) or between Daphnia biomass in March and the NAO ( $r=-0.4$, n.s.).

High Daphnia biomasses were associated with negative increase rates of phytoplankton biovolume during May $(r=-0.69, P<0.005$; Fig. 4 a) and an early start of the clear-water phase $(r=-0.84, P<0.001$; Fig. $4 \mathrm{~b})$. The onset of the clear-water phase in Lake Constance varied by approximately 1 month between years, e.g., from the middle of May in 1990 to the end of June in 1987, and was related to the NAO index $(r=-0.55, P<0.05$; Table 1$)$. Additionally, there was a tendency for longer clear-water periods when they started earlier (correlation coefficient between the duration of the clear-water phase and (a) its starting date: $r=-0.58, p<0.05$; and (b) the NAO Index: $r=0.46, P<0.09)$.

The daphnid biomass in July was positively related to the start of the clear-water phase $(r=0.63, P<0.05)$ and negatively to daphnid biomass in May (Fig. 5a). Thus, Daphnia biomass in July was lower during high NAO years $(r=-0.58, P<0.05$; Fig. $5 b)$. Monthly averages of daphnid biomass in July varied by approximately one or- 

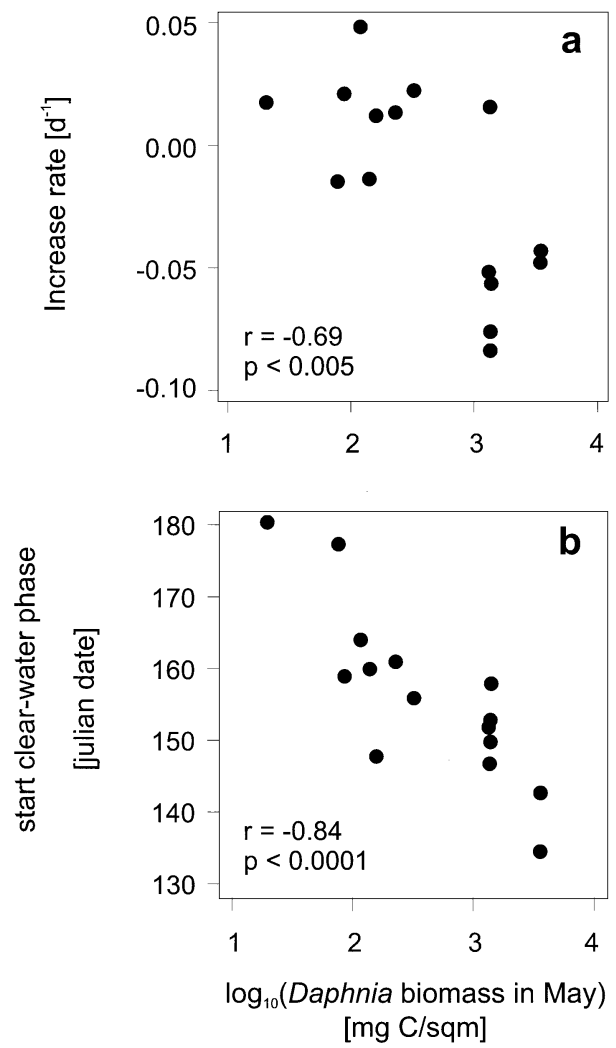

Fig. 4 Relationship between the average Daphnia biomass in May and phytoplankton growth rate during May (a), and the start of the clear-water phase (b)

der of magnitude, whereas May averages exhibited an interannual variability exceeding two orders of magnitude (Fig. 5a). Only during high-NAO years (1989, 1990, 1993) did biomass in May exceed July biomass, whereas in all other years, July biomass was larger than May biomass (Fig. 5a). The maximum monthly average of Daphnia biomass during late spring and early summer was not correlated with the NAO index $(r=-0.21$, n.s.). Daphnid biomass in July was neither related to phosphorus concentrations during winter mixing ( $r=0.14$, n.s.) nor to the year-class strength of whitefish $(r=-0.04$, n.s.).

\section{Discussion}

The measurements described here suggest a causal chain of meteorological, hydrological, and ecological processes connecting a large-scale meteorological phenomenon together with winter and early spring meteorological conditions to planktonic events in summer. Climatic conditions in Europe are influenced by the NAO predominantly in winter when it is strongest and has the clearest teleconnections (Barnston and Livezy 1987). Accordingly, the NAO signal is detectable in Constance air temperatures during winter, and in the water temperatures of Lake Constance until May. Elevated water temperatures during recent winters, i.e., high-NAO years, have been
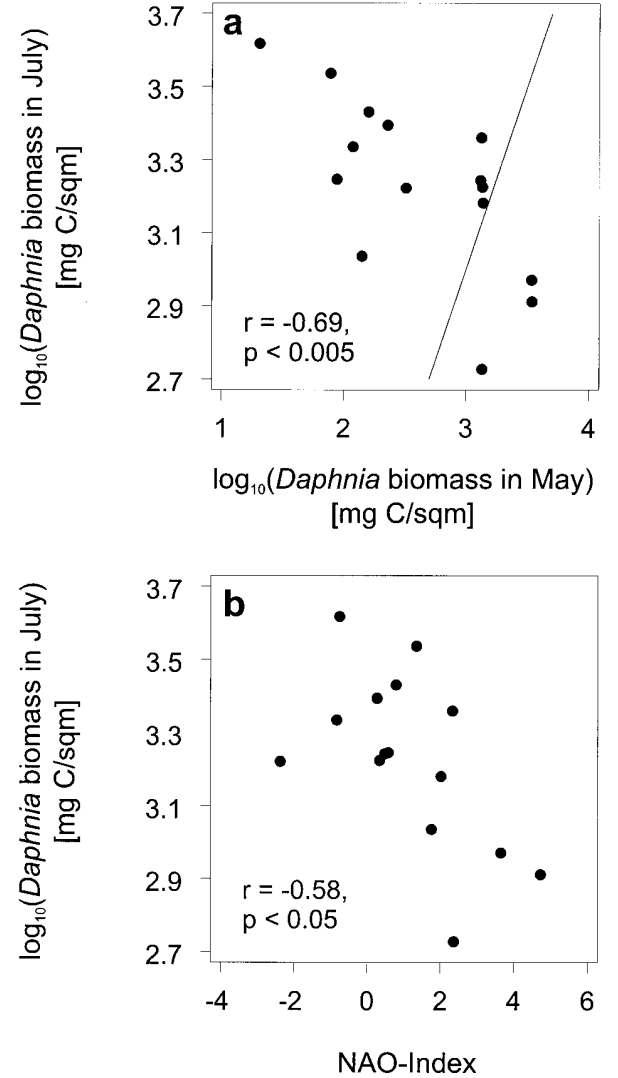

Fig. 5 a Relationship between average daphnid biomass in July and average Daphnia biomass in May. For a better comparison of absolute values, the line where May biomass would equal July biomass is shown. b Relationship between average Daphnia biomass in July and the NAO index

recorded in a number of European lakes and coastal waters (Beukema 1992; Pingree 1994; Adrian et al. 1995; Müller-Navarra et al. 1997; Kröncke et al. 1998).

Water temperature and the heat content of a lake are major factors in determining the onset of thermal stratification in spring (McCormick 1990; Robertson and Ragotzke 1990; Demers and Kalff 1993). Thermal stratification reduces downward mixing of heat yielding a stronger stratification which, in turn, again enhances the warming of surface waters. Hence, the start of stratification initiates a positive feedback mechanism which may accelerate the meteorological signal.

As soon as mixing below the euphotic zone ceased, algal standing stocks increased substantially in deep Lake Constance (Bäuerle et al. 1998; Gaedke et al. 1998). Ciliates and rotifers responded rapidly to an initial increase in phytoplankton biomass (Müller et al. 1991; Arndt et al. 1993) and exhibited a strong grazing pressure on phytoplankton shortly thereafter (Müller et al. 1991; Arndt et al. 1993; Gaedke and Straile 1994). Thus, the resulting phytoplankton biomass is due to the combined effect of phytoplankton growth and the grazing pressure by small herbivores shortly after the onset of stratification. These differences in the increase patterns, i.e., positive feedback of temperature increase ver- 
sus dampening of phytoplankton biomass increase due to grazing, might explain why a strong relationship was observed between water temperatures and the NAO, but not between phytoplankton biomass and the NAO.

During the investigation period, daphnid population growth started around April (Fig. 3). At this time, phytoplankton biomass was already high and influenced by small herbivores (see above), so that daphnids were not associated with higher phytoplankton biomasses, but with higher water temperatures after high-NAO compared to low-NAO years. In laboratory studies, temperature has strong effects on the feeding and growth of daphnids (Vijverberg 1980; Lampert and Muck 1985). Additionally, daphnid food demands to obtain a certain growth rate decrease with decreasing temperatures (Achenbach and Lampert 1997). This reduces the possible impact of food limitation on Daphnia growth during April when water temperatures are still low. Thus, variability in daphnid population growth was probably a direct effect of variability in water temperatures but was not mediated by phytoplankton biomass.

Critical Daphnia biomasses able to suppress phytoplankton biomass were reached in May during highNAO years and resulted in an earlier onset of the clearwater phase. The clear-water phase is a regular successional event in many temperate lakes (Lampert 1978; Luecke et al. 1990; Markager et al. 1994; Angeli et al. 1995), and has been traced back to the grazing impact of daphnids (Lampert et al. 1986), which are the dominant herbivores in Lake Constance at this time of the year (Pinto-Coelho 1991; Straile 1998). The timing of the clear-water phase in the small and eutrophic Plußsee $\left(0.14 \mathrm{~km}^{2}, z_{\text {mean }}=9.4 \mathrm{~m}\right)$ was correlated with the mean annual lake temperature (Müller-Navarra et al. 1997). The authors assumed that the earlier onset of the clearwater phase with increased temperatures was due to temperature-controlled zooplankton growth under high algal abundances in spring but, unfortunately, they did not present data on zooplankton and phytoplankton. Additionally, a comparative analysis of interannual variability in the timing of the clear-water phase and Daphnia population dynamics during spring in the small and hypertrophic Müggelsee $\left(7.3 \mathrm{~km}^{2}, z_{\text {mean }}=4.9 \mathrm{~m}\right)$ and Lake Constance revealed that both lakes exhibited a high temporal coherence, i.e., an early clear-water phase in Müggelsee was associated with an early clear-water phase in Lake Constance (D. Straile and R. Adrian, unpublished data) These results suggest that similar mechanisms determine interannual variability in successional events during the first half of the year in lakes of different size and trophy.

The trophic state of Lake Constance has changed from meso-eutrophic to more oligotrophic conditions during the study period (Gaedke and Schweizer 1993; Güde et al. 1998). A potential confounding of meteorological and trophy effects during spring can be excluded because phytoplankton did not respond to reoligotrophication during spring (Gaedke and Schweizer 1993). Despite decreased phosphorus concentrations, daphnids grew faster in spring in recent years when water temperatures were high. In summer, concentrations of edible algae and primary production remained largely unchanged (Tilzer et al. 1991; Gaedke and Schweizer 1993). Daphnid biomass in July was not related to winter phosphorus concentrations and hardly any response of the zooplankton community to declining nutrient concentrations was observed (Straile and Geller 1998a, 1998b). Likewise, interannual differences in the year-class strength of underyearling whitefish (C. lavaretus), the dominant planktivores in Lake Constance, were not related to Daphnia biomass. This suggests that the results were neither confounded by changes in the trophic state of the lake, nor by interannual changes in predation pressure by whitefish.

The effects of the NAO and spring water temperatures on plankton succession were of varying complexity. Some planktonic responses may be understood as simple temporal shifts of successional events. For example, the inverse relationship between Daphnia biomasses in May and July was probably caused by a temporal shift in Daphnia population dynamics, which is characterized by maximum abundances during late spring/early summer and a subsequent summer decline (Sommer et al. 1986). During years with a low NAO index, Daphnia growth was slow and high biomasses were obtained in July. In contrast, during high-NAO years, biomass was high in May and declined towards July. However, this shift in the timing of maximum biomass did not affect the overall magnitude of maximum biomass during spring, which was not related to the NAO.

On the other hand, there is also evidence for alternations in the complex patterns of plankton regulation due to meteorological forcing. For example, daphnids and algae were controlled by different mechanisms during early spring, allowing a possible uncoupling of algal and daphnid dynamics. The seasonal increase in daphnid biomass in Lake Constance closely followed the seasonal rise in epilimnetic water temperatures during spring. In contrast, phytoplankton growth was tightly coupled to increased light availability, i.e., a reduction in mixing depth (Gaedke et al. 1998). As periods without mixing occurred in some years during late winter and early spring when water temperatures were still low, algae but not daphnids started to grow (Gaedke et al. 1998). Because ciliates were able to react almost immediately to increased algal biomass (Müller et al. 1991), this suggests that the relative importance of ciliates as herbivores is larger in low-NAO years than in high ones.

The duration of the clear-water phase provides a second example of an alternation in the importance of processes in response to the speed of vernal warming. During low-NAO years, the clear-water phase was less pronounced and lasted only a few days. There are several potential mechanisms for this pattern. (a) A succession of phytoplankton towards species which are highly competitive at low phosphorus concentrations, e.g., the diatoms Fragillaria and Asterionella, in response to the seasonal decline of phosphorus concentrations (Sommer et al. 1986). As these species are also large, this may reduce the overall edibility of phytoplankton and hence the 
duration and intensity of the clear-water phase if Daphnia reach peak abundances after the occurrence of this successional shift. (b) Diel vertical migration (DVM) of $D$. hyalina, which in Lake Constance usually starts around June (Geller 1986). If the biomass-specific grazing pressure of daphnids integrated over 1 day is already reduced by DVM, a less pronounced clear-water phase may be expected.

Meteorological forcing of daphnid population dynamics probably affects the population dynamics of many other planktonic species and, consequently, ecosystem processes. The triggering of the clear-water phase is the most impressive - even macroscopically observable demonstration of the grazing potential of daphnids. Besides grazing on phytoplankton, daphnids exert a significant grazing pressure on all components of the microbial food web (Jürgens 1994), and suppress rotifers (Gilbert 1988) and copepod nauplii (Santer and Lampert 1995) by exploitative and interference competition. As a result, a lower daphnid biomass during July in high-NAO years will partly relieve rotifers and protozoans from competition and predation yielding a higher species and carbon flux diversity and increasing the importance of the microbial loop (Gaedke and Straile 1994; Straile 1998).

To conclude, population dynamics of daphnids and the timing of important successional events in the plankton community of Lake Constance were subject to meteorological forcing by the NAO. The winter NAO signal did not fade and was detected in the interannual variability of various parameters until July. The system exhibited a remarkable memory over almost half of the year due to the important role played by Daphnia in plankton succession. A thorough understanding of the regulation of Daphnia population dynamics is therefore a key for predictions of the response of freshwater planktonic food webs to global climate change.

Acknowledgements Data acquisition was performed within the Special Collaborative Program (SFB) 248 "Cycling of Matter in Lake Constance" supported by the Deutsche Forschungsgemeinschaft (DFG). Data analysis was supported by the EU project "Response of European Freshwater Lakes to Environmental and ClimaTic change (REFLECT, contract number: ENV4-CT97-0453)." Special thanks to B. Beese, U. Gaedke, W. Geller, J. Hurrell, D. Ollinger, R. Rösch, the Institut für Seenforschung/Langenargen, and the German Weather Service who provided data for this study. Comments by Ursula Gaedke, Erich Bäuerle, and three referees greatly improved the style and content of the manuscript.

\section{References}

Achenbach L, Lampert W (1997) Effects of elevated temperatures on threshold food concentrations and possible competitive abilities of differently sized cladoceran species. Oikos 79:469-476

Adrian R, Deneke R (1996) Possible impact of mild winters on zooplankton succession in eutrophic lakes of the Atlantic European area. Freshwater Biol 36:757-770

Adrian R, Deneke R, Mischke U, Stellmacher R, Lederer P (1995) A long-term study of the Heiligensee (1975-1992): evidence for effects of climatic change on the dynamics of eutrophied lake ecosystems. Arch Hydrobiol 133:315-337
Aebischer NJ, Coulson JC Colebrook JM (1990) Parallel longterm trends across four marine trophic levels and weather. Nature 347:753-755

Anderson WL, Robertson DM, Magnuson JJ (1996) Evidence of recent warming and El Niño-related variations in ice breakup of Wisconsin lakes. Limnol Oceanogr 41:815-821

Angeli N, Pinel-Alloul B, Balvay G, Ménard I (1995) Diel patterns of feeding and vertical migration in daphnids and diaptomids during the clear water phase in Lake Geneva (France). Hydrobiologia 300/301:163-184

Arndt H, Krocker M, Nixdorf B, Köhler A (1993) Long-term annual and seasonal changes of meta- and protozooplankton in Lake Müggelsee (Berlin): effects of eutrophication, grazing activities, and the impact of predation. Int Rev Ges Hydrobiol 78:379-402

Barber RT, Chavez FP (1983) Biological consequences of El Niño. Science 222:1203-1210

Barnston AG, Livezy RE (1987) Classification, seasonality and persistence of low-frequency atmospheric circulation patterns. Mon Weather Rev 155:1083-1126

Bäuerle E, Ollinger D, Ilmberger J (1998) Some meteorological, hydrological, and hydrodynamical aspects of Upper Lake Constance. Arch Hydrobiol Spec Issues Adv Limnol 53:31-83

Beukema JJ (1992) Expected changes in the Wadden Sea benthos in a warmer world: lessons from periods with mild winters. Neth J Sea Res 30:73-79

Davies TD, Viner D, Jones PD (1998) Changes in atmospheric circulation and climate over the North Atlantic and Europe. In: George DG, Jones JG, Puncochár P, Reynolds CS, Sutcliffe DW (eds) Management of lake and reservoirs during global climate change. Kluwer, Dordrecht, pp 1-13

Demers E, Kalff J (1993) A simple model for predicting the date of spring stratification in temperate and subtropical lakes. Limnol Oceanogr 38:1077-1081

Eckmann R, Rösch R (1998) Lake Constance fisheries and fish ecology. Arch Hydrobiol Spec Issues Adv Limnol 53:285301

Eckmann R, Gaedke U, Wetzlar HJ (1988) Effects of climatic and density-dependent factors on year-class strength of Coregonus lavaretus in Lake Constance. Can J Fish Aquat Sci 45:10881093

Fraedrich K, Müller K (1992) Climate anomalies in Europe associated with ENSO extremes. Int J Climatol 12:25-31

Fromentin J-M, Planque B (1996) Calanus and environment in the North Atlantic. II. Influence of the North Atlantic Oscillation on $C$. finmarchicus and C. helgolandicus. Mar Ecol Prog Ser 134:111-118

Fromentin J-M, Stenseth NC, Gjosaeter J, Johannessen T, Planque B (1998) Long-term fluctuations in cod and pollack along the Norwegian Skagerrak coast. Mar Ecol Prog Ser 162:265-278

Gaedke U (1993) Ecosystem analysis based on biomass size distributions: a case study of a plankton community in a large lake. Limnol Oceanogr 38:112-127

Gaedke U, Schweizer A (1993) The first decade of oligotrophication in Lake Constance. I. The response of phytoplankton biomass and cell size. Oecologia 93:268-275

Gaedke U, Straile D (1994) Seasonal changes of the quantitative importance of protozoans in a large lake: an ecosystem approach using mass-balanced carbon flow diagrams. Mar Microb Food Webs 8:163-188

Gaedke U, Ollinger D, Bäuerle E, Straile D (1998) The impact of weather conditions on the seasonal plankton development. Arch Hydrobiol Spec Issues Adv Limnol 53:565-585

Geller W (1986) Diurnal vertical migration of zooplankton in a temperate great lake (L. Constance): a starvation avoidance mechanism? Arch Hydrobiol [Suppl] 74:1-60

Geller W (1989) The energy budget of two sympatric Daphnia species in Lake Constance: productivity and energy residence times. Oecologia 78:242-250

Geller W, Müller H (1985) Seasonal variability in the relationship between body-length and individual dry weight as related to food abundance and clutch size in two coexisting Daphnia species. J Plankton Res 7:1-18 
George DG, Harris GP (1985) The effect of climate on long-term changes in the crustacean zooplankton biomass of Lake Windermere, UK. Nature 316:536-539

George DG, Taylor AH (1995) UK lake plankton and the Gulf stream. Nature 378:139

Gilbert JJ (1988) Susceptibilities of ten rotifer species to interference from Daphnia pulex. Ecology 69:1826-1838

Güde H, Rossknecht H, Wagner G. (1998) Anthropogenic impacts on the trophic state of Lake Constance during the 20th century. Arch Hydrobiol Spec Issues Adv Limnol 53:85-108

Harris GP, Davies P, Nunez M, Meyers G (1988) Interannual variability in climate and fisheries in Tasmania. Nature 333:754-757

Hurrell JW (1995) Decadel trends in the North Atlantic Oscillation: regional temperatures and precipitation. Science 269:676-679

Jürgens K (1994) Impact of Daphnia on planktonic microbial food webs - a review. Mar Microb Food Webs 8:295-324

Karl DM, Letelier R, Hebel D, Tupas L, Dore J, Christian J, Winn C (1995) Ecosystem changes in the North Pacific subtropical gyre attributed to the 1991-1992 El-Niño. Nature 373:230234

Kröncke I, Dippner JW, Heyen H, Zeiss B (1998) Long-term changes in macrofaunal communities off Norderney (East Frisia, Germany) in relation to climate variability. Mar Ecol Prog Ser 167:25-36

Lamb PJ, Peppler RA (1987) North Atlantic Oscillation: concept and an application. Bull Am Meteorol Soc 68:1218-1225

Lampert W (1978) Climatic conditions and planktonic interactions as factors controlling the regular succession of spring algal bloom and extremely clear water in Lake Constance. Verh Int Ver Limnol 20:969-974

Lampert W, Muck P (1985) Multiple aspects of food limitation in zooplankton communities: the Daphnia-Eudiaptomus example. Arch Hydrobiol Beih Ergebn Limnol 21:311-321

Lampert W, Fleckner W, Rai H, Taylor BE (1986) Phytoplankton control by grazing zooplankton: a study on the spring clearwater phase. Limnol Occeanogr 31:478-490

Luecke C, Vanni MJ, Magnuson JJ, Kitchell JF, Jacobson PT (1990) Seasonal regulation of Daphnia populations by planktivorous fish: implications for the spring clear-water phase. Limnol Ocenaogr 35:1718-1733

Markager S, Hansen B, Søndergaard M (1994) Pelagic carbon metabolism in a eutrophic lake during a clear-water phase. J Plankton Res 16:1247-1267

McCormick MJ (1990) Potential changes in thermal structure and cycle of lake Michigan due to global warming. Trans Am Fish Soc 119:183-194

Müller H, Schöne A, Pinto-Coelho RM, Schweizer A, Weisse T (1991) Seasonal succession of ciliates in Lake Constance. Microbiol Ecol 21:119-138
Müller-Navarra DC, Güss S, Storch H von (1997) Interannual variability of seasonal succession events in a temperate lake and its relation to temperature variability. Global Change Biol $3: 429-438$

Pingree RD (1994) Winter warming in the southern bay of Biscay and lagrangian eddy kinematics from a deep-drogued argos buoy. J Mar Biol Assoc UK 74:107-128

Pinto-Coelho RM (1991) The importance of Daphnia for zooplankton grazing in Lake Constance. Arch Hydrobiol 121:319-342

Post E, Stenseth NC (1998) Large-scale climatic fluctuation and population dynamics of moose and white-tailed deer. J Anim Ecol 67:537-543

Robertson DM, Ragotzke RA (1990) Changes in the thermal structure of moderate to large sized lakes in response to changes in air temperature. Aquat Sci 52:360-380

Roemmich D, McGowan J (1995) Climatic warming and the decline of zooplankton in the California Current. Science 267:1324-1326

Santer B, Lampert W (1995) Summer diapause in cyclopoid copepods: adaptive response to a food bottleneck? J Anim Ecol 64:600-613

SAS (1988) SAS/STAT user's guide, release 6.03 edition. SAS Institute, Cary, NC

Simon M, Tilzer MM (1987) Bacterial response to seasonal changes in primary production and phytoplankton biomass in Lake Constance. J Plankton Res 9:535-552

Sommer U, Gliwicz ZM, Lampert W, Duncan A (1986) The PEGmodel of seasonal succession of planktonic events in fresh waters. Arch Hydrobiol 106:433-471

Straile D (1998) Biomass allocation and carbon flow in the pelagic food web of Lake Constance. Arch Hydrobiol Spec Issues Adv Limnol 53:545-563

Straile D, Geller W (1998a) The response of Daphnia to changes in trophic status and weather patterns: a case study from Lake Constance. ICES J Mar Sci 55:775-782

Straile D, Geller W (1998b) Crustacean zooplankton in Lake Constance from 1920 to 1995: response to eutrophication and reoligotrophication. Arch Hydrobiol Spec Issues Adv Limnol $53: 255-274$

Strub PT, Powell T, Goldman CR (1985) Climatic forcing: effects of El Niño on a small, temperate lake. Science 227:55-57

Tilzer MM, Beese B (1988) The seasonal productivity cycle of phytoplankton and controlling factors in Lake Constance. Schweiz Z Hydrol 50:1-39

Tilzer MM, Gaedke U, Schweizer A, Beese B, Wieser T (1991) Interannual variability of phytoplankton productivity and related parameters in Lake Constance: no response to decreased phosphorus loading? J Plankton Res 13:755-777

Vijverberg J (1980) Effect of temperature in laboratory studies on development and growth of Cladocera and Copepoda from Tjeukemeer, The Netherlands. Freshwater Biol 10:317-340 